\title{
Correction to: Quality Management and Accreditation in Hematopoietic Stem Cell Transplantation and Cellular Therapy
}

\author{
Mahmoud Aljurf, John A. Snowden, Patrick Hayden, Kim H. Orchard, \\ and Eoin McGrath
}

\section{Correction to:}

M. Aljurf et al. (eds.), Quality Management and Accreditation in Hematopoietic Stem Cell Transplantation and Cellular Therapy, https://doi.org/10.1007/978-3-030-64492-5

The book was inadvertently published with incorrect affiliation for the below volume editors in the copyright page. It has been updated in this version as follows:

John A. Snowden: From "Department of Haematology, University of Sheffield, Sheffield, UK"

to

"Sheffield Teaching Hospitals NHS Foundation Trust and The University of Sheffield, Sheffield, UK"

Patrick Hayden: From "St. James’s Hospital, Dublin, Ireland" to

"St. James's Hospital and Trinity College Dublin, Dublin, Ireland" 
Open Access This chapter is licensed under the terms of the Creative Commons Attribution 4.0 International License (http://creativecommons.org/licenses/by/4.0/), which permits use, sharing, adaptation, distribution and reproduction in any medium or format, as long as you give appropriate credit to the original author(s) and the source, provide a link to the Creative Commons license and indicate if changes were made.

The images or other third party material in this chapter are included in the chapter's Creative Commons license, unless indicated otherwise in a credit line to the material. If material is not included in the chapter's Creative Commons license and your intended use is not permitted by statutory regulation or exceeds the permitted use, you will need to obtain permission directly from the copyright holder. 